\section{教 室}

\section{Q \&A}

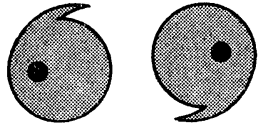

\section{コンクリート打設後散水養生 するのはなぜですか?}

コンクリート打込み後の養生の主な目的は，

1）強度及び耐久性の増進を図る,

2）乾燥などによるひびわれを防止する，

3）適温を保持し，凍害等を防ぐ，

ですから，良いコンクリート構造物を得るためには，養 生は欠かせない重要な作業となります。しかし，主とし て工程上の制約等から，往々にしておろそかにされがち でもあります。

養生の方法を分類すると，一例として次のようになり ます。

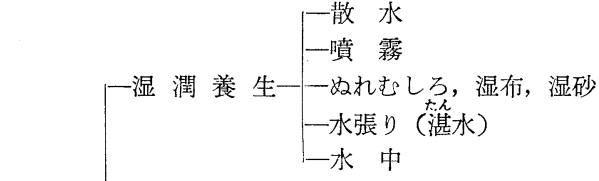

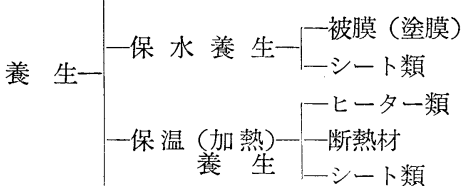

$$
\begin{aligned}
& \text { 一特殊 養生一一蒸 诵 }
\end{aligned}
$$

この中で，散水，噴霧などの湿潤養生は，セメントの 水和作用の点からも，急激な乾燥を避けるといら点から も極めて効果的です。このため，JASS $5^{1)}$ 及びR C 示 方書 ${ }^{2}$ でも，「養生」の部分で，湿潤養生を行うよう規定 しています。

湿潤養生の効果を, 前述の養生の目的に照らして見て みましょう。

図一1は, 初期湿潤養生期間の長短がコンクリートの 圧縮強度発現に及ぼす影響を示したものですが，これを 見ても，湿潤養生をしない場合には，初期に 3 日間湿潤 養生した場合の約 70\%，更に初期に 14 日間湿潤養生
[配合］ W/C : $50 \%$ 細骨材率：36\% スランプ: $9 \mathrm{~cm}$ 空気量: $4 \%$ セメント量： $330 \mathrm{~kg} / \mathrm{m}^{3}$

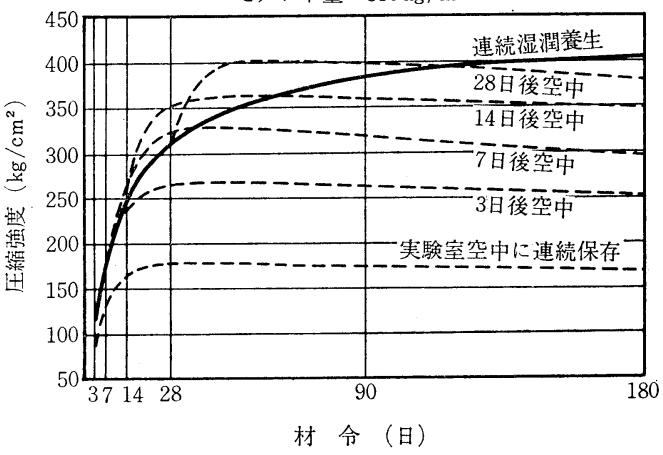

図一1初期湿潤養生後, 実験室空気中で乾燥した コンクリートの圧縮強度 ${ }^{3}$

した場合と比較すると約 $50 \%$ の強度発現しか見ないこ とがわかります。また，コンクリートの耐久性には水密 性の影響が大きく，水密性を高めるためには，湿潤養生 期間はできるだけ長い方がよいとされており，JASS 5 でも，水密コンクリートの場合には，湿潤養生期間を一 般の場合より長くとるように規定しています。

ひびわれ防止に関連して言えば，乾燥収縮は湿潤養生 期間が短いほど大きいと考えられがちですが，このこと を明確に示すデータはない上うです。ただし，コンクリ 一ト硬化時のプラスチックひびわれは，その原因が急激 な乾燥であり，初期の湿潤養生は，これらのひびわれの 防止法として非常に効果的です。

凍害に関しても，乾燥ひびわれ等の防止は凍害防止と 深い関係があるので，湿潤養生を十分に行うことは必要 なことです。

以上述べたことから, コンクリート打込み後, 表面に 傷がつかない程度に硬化したならば，なるべく早くから 散水などの湿潤養生を十分に行うことが極めて大切なこ とであり，その期間は，普通ポルトランドセメントを使 用した場合, JASS 5 及びR C 示方書に示されている最 低 5 日間を守るのが，良いコンクリート構造物を造り上 げるために必要不可欠のことと言えるでしょう。

$$
\text { 参考文 献 }
$$

1）建築工事標準仕様書・同解説 JASS 5 鉄筋コンクリート 工事, 日本建築学会

2）コンクリート標準示方書, 土木学会

3）アメリカ内務省 開拓局編, 近藤泰夫訳 : コンクリートマ ニュアル・第 8 版, 国民科学社, 1978

4）日本コンクリート工学協会編：コンクリート便覽，技報 堂, 1976

5）施工, 彰国社, 1978 年 6 月号

6）塚山隆一：コンクリート技術基礎教室 $\langle 17>\quad \mathrm{V}$. 施工 3. 養生, コンクリートジャーナル, Vol. 10, No. 5, 1972. 5

（高橋 勉） 


\section{コンクリートの強度はどの位まで 強くできるのでしょうか?}

近年, コンクリートの高強度化はめざましく, 圧縮強 度が $400 \mathrm{~kg} / \mathrm{cm}^{2}$ 程度のものは普通に用いられており, 更に圧縮強度が $1000 \mathrm{~kg} / \mathrm{cm}^{2}$ 程度までの高強度コンク リートの実用化が進められています。

コンクリートの高強度化はどこをで可能であるかを考 える場合, 一つの目安となるセメントペーストの限界強 度は, 圧縮強度 数千 $\mathrm{kg} / \mathrm{cm}^{2}$, 引張強度 数百 $\mathrm{kg} / \mathrm{cm}^{2}$ と 推定され ${ }^{1)}$, 実際にホットプレス $\left(250^{\circ} \mathrm{C}\right.$ で $3500 \mathrm{~kg} / \mathrm{cm}^{2}$ の圧力を加える) によって, 圧縮強度 $6650 \mathrm{~kg} / \mathrm{cm}^{2}$, 引 張強度 $648 \mathrm{~kg} / \mathrm{cm}^{2}$ が達成されています ${ }^{2)}$ 。

コンクリートでは, 骨材とセメントペーストとの付 着, 骨材の存在による応力集中などの問題がありますか ら, 限界強度はセメントペーストの場合よりも小さくな ると思われますが, 現在の強度と比較すれば, まだまだ 高強度化の余地があると言えます。

コンクリートを高強度化する方法は現在種々試みられ ており，表一1 はその原理と実績を示したものです ${ }^{3)} 。$ このうち, 現時点で最も実用化されているのは, 高性 能減水剤を使用する方法と高温高圧（オートクレーブ） 養生による方法で, 既に圧縮強度 $1000 \mathrm{~kg} / \mathrm{cm}^{2}$ 程度の コンクリートを造ることが可能ですが, その場合, 骨材 が十分高強度であることが要求されます。また 表一2 に 示すように，これらの方法では，圧縮強度の増進の割に は曲げ強度や引張強度は増進しません。圧縮, 曲げ, 引 張, せん断などすべての面での高強度コンクリートを目 指すには, 今後骨材そのものの品質向上と, 骨材とセメ
表-2 高強度コンクリートの圧縮, 曲(゙, 引張強度 ${ }^{4)}$

$\left(\mathrm{kg} / \mathrm{cm}^{2}\right)$

\begin{tabular}{|c|c|c|c|}
\hline 種別 & $\begin{array}{c}\text { 減水剂使用 } \\
\text { コンクリート } \\
\text { (水中養生 } 28 \text { 日) }\end{array}$ & $\begin{array}{l}\text { クリンカー } \\
\text { コンクリート } \\
\text { (水中養生 } 28 \text { 日) }\end{array}$ & $\begin{array}{c}\text { オートクレ } \\
\text { ープ養生コ } \\
\text { ンク纱 } \\
\text { (減水剂使用) }\end{array}$ \\
\hline 圧縮強度 & 981 & 844 & 913 \\
\hline 曲げ強度 & $\begin{array}{l}96 \\
(9.7)\end{array}$ & $\begin{array}{l}135 \\
(14.8)\end{array}$ & $\begin{array}{l}80 \\
(8.8)\end{array}$ \\
\hline 引張強度 & $\begin{array}{l}64.8 \\
(6.6)\end{array}$ & $\begin{array}{l}65.2 \\
(6.9)\end{array}$ & $\begin{array}{l}53 \\
(5.8)\end{array}$ \\
\hline
\end{tabular}

注）表中（）内数字は圧縮強度に対する比率（\%) を示す。

ントペーストとの付着力強化を図らなければならないで しょ5。

西歴 2000 年においては, 圧縮強度が $1400 \mathrm{~kg} / \mathrm{cm}^{2}$ 程 度のコンクリートが一般に使用され, また特殊な目的に 対しては, 圧縮強度が $4000 \mathrm{~kg} / \mathrm{cm}^{2}$ 程度のコンクリー トが製造されるであろらという予測が立てられていま す5)。高強度コンクリートの一般化がこれから始まると 言えるでしょう。

\section{参 考 文 献}

1）小柳 洽 : コンクリートの高強度化とその限界, コンク リート工学, Vol. 14, No. 3, 1976.3

2) D.M. Roy and G.R. Gouda : High Strength Generation in Cement Pastes, Cement and Concrete Research, Vol. 3, No. 6, 1973

3）コンクリート工学編集委員会 : コンクリートの強度への 挑戦, コンクリート工学, Vol. 14, No. 3, 1976.3

4）長滝重義 : 高強度 コンクリートの諸性質, コンクリート 工学, Vol. 14, No. 3, 1976.3

5) ACI Ad Hoc Board Commitee Report : Concrete-Year 2000 , ACI Journal, Vol. 68, 1971, pp. 581 589

(飯田一彦)

表一1＼cjkstart高強度コンクリートの実施例 ${ }^{3)}$

\begin{tabular}{|c|c|}
\hline 原 理 と 方 法 & 状 \\
\hline 強力な減水剂による水セメント比の低減 & 現場打ちコンクリートで設計基準強度 $600 \mathrm{~kg} / \mathrm{cm}^{2}$ の実績あり。 \\
\hline 活性骨材による付着の改善 & セメントクリンカー骨材により $1200 \mathrm{~kg} / \mathrm{cm}^{2}$ に達した実験報告あり。 \\
\hline 高温高圧養生による水和物の改善 & シリカ粉末または減水剤と併用し $1000 \mathrm{~kg} / \mathrm{cm}^{2}$ が可能。コンクリート製品で実施。 \\
\hline $\begin{array}{l}\text { 加圧による空陗(げき)率と水セメント比 } \\
\text { の低減 }\end{array}$ & $\begin{array}{l}\text { （1） セxントペーストのホットプレスで } 6000 \mathrm{~kg} / \mathrm{cm}^{2} \text { 以上となった報告あり。 } \\
\text { (1973 年, Roy) } \\
\text { (2) コンクリートで } 1160 \mathrm{~kg} / \mathrm{cm}^{2} \text { を達成している。(1940 年, 吉田徳次郎) } \\
\text { (3) コンクリート製品製造に応用されている。 }\end{array}$ \\
\hline ポリマーの利用による各種改善 & $\left.\begin{array}{l}\text { (1) ポリマーセメントコンクリート } \\
\text { (2) レジンコンクリート } \\
\text { (3) ポリマー含浸コンクリート }\end{array}\right\}$ 各種分野への応用が増加している。 \\
\hline 繊維による補強 & 鋼繊維及びガラス繊維の利用につき活発な用途開発が行われている。 \\
\hline
\end{tabular}

